\title{
APPLICATION OF SALICYLIC ACID AND SOME FUNGICIDES AS SEED TREATMENT FOR CONTROLLING DAMPING-OFF AND ROOT ROT DISEASES OF SQUASH AND CANTALOUPE PLANTS UNDER FIELD CONDITIONS. Gehad M. Mohamed ${ }^{1}$ and Saida M. Amer ${ }^{2}$ \\ ${ }^{1}$ Vegetable diseases Res. Dept., Plant Pathology Institute, ARC, Giza, Egypt. \\ 2 Botany Department, Faculty of Science, Tanta University, Tanta, Egypt.
}

\begin{abstract}
The effect of salicylic acid (SA) individually or/and in combinations with three standard fungicides named Flutolanil (Moncut WP 30\%), Telcolofos-methyl/thiram (Rhizolex 50\%WP) and Carboxin-Thiram (Vitavax 200 WP) was studied for the field control of damping-off and root rot diseases of cantaloupe (Cucumis melo var. cantaloupensis) and squash (Cucurbita pepo), cvs Askandarany and Mera, respectively. The experiments were carried out in the years 2012 and 2013.

In vitro studies the effect of the aforementioned fungicides and salicylic acid on growth of Rhizoctonia solani and Fusarium solani was determined. The effective concentration was found to range from 50 to $200 \mathrm{ppm}$, and the higher concentration the greater inhibitory effect. The combination of salicylic and vitavax 200 and salicylic acid and Rizolex at $200 \mathrm{ppm}$ showed the highest effect on $R$. solani and $F$. solani with the averages of $84.75,86.79,71.25$ and $87.13 \%$, respectively.

In field trials, soaking seeds in salicylic acid, either single or in combination with the fungicides in concern, significantly decreased both damping-off and root rot of squash and cantaloupe. In addition to increasing the numbers of survived plants, the used treatments increased shoot length as well as fresh and dry weights. The results showed that mixed salicylic acid application with fungicides to seeds of squash and cantaloupe significantly decreased disease symptoms by 70.32 and $64.07 \%$ for vitavax 200 and rhizolex treatments, respectively, for squash. The corresponding figures for cantaloupe were 62.89 and $55.90 \%$, respectively in the second season 2013. Moreover, the treatments in concern increased the activities of peroxidase and polyphenoloxidase. It is noticed, however, a negative correlation between disease incidence and activities of both peroxidase and polyphenoloxidase in either squash or cantaloupe plants. Meanwhile, the treatments in concern increased the contents of $\mathrm{Mn}$ and Fe but decreased $\mathrm{Zn}$ of both tested crops

In general, the results indicated that especially the combined SA and standard fungicides showed a better response to fight damping-off and root rot diseases than the treatment alone. Thus the present study shows that the induction of defense related enzymes may be enhance resistance in squash and cantaloupe plants.
\end{abstract}

\section{INTRODUCTION}

Cantaloupe (Cucumis melo var. cantaloupensis) and summer squash (Cucurbita pepo) are considered of the major summer vegetable crops in commercial fields and under protected cultivation during winter in Egypt. They are considered a major source of essential nutrients such as vitamins, minerals, carbohydrates, antioxidants and anti carcinogenic substances, 
which are important to human nutrition and health (Joseph, 1994). The cultivated area under Beheria Governorate conditions of cantaloupe and squash during 2013 season were 3023 and 8962 feddans yielded about 6-8 and 12-16 tons / feddan of fruits, respectively.

Cultivated vegetables are subjected to attack by several plant pathogenic fungi during different stages of plant growth from seed sowing up to seedling to flowering stages, and may to cause pre-emergence infection, thus forcing the farmer to replant the missed hills or dead plants. Moreover, root rot disease, produced by Pythium spp., Rhizoctonia spp., Sclerotinia spp. and Fusarium spp. cause widespread, serious economic losses both in greenhouse and field production systems under conditions favorable for the disease development (Celar, 2000 and Hibar et al., 2006). In Egypt, Alternaria solani, F. oxysporum, R. solani, Sclerotium rolfsii, Macrophomina phaseolina and Pythium spp. were isolated from diseased cucumber, cantaloupe, tomato and pepper plants grown in plastic houses and showing root rot disease symptoms (El-Mougy et al., 2011 and Abdel-Kader et al., 2012).

The most efficient and economically vital method for disease control is the use of resistant varieties (Wada, 2003). However, the development of resistant varieties is time consuming, until now; therefore fungicides have been described as the primary means of quick control (Olufolaju, 1993). Rukhsana Afzal et al. (2010) reported that the fungicidal seed treatment is highly effective, economical and easily applicable, as it can reduce the seedborne mycoflora, improveing seed germination and protecting seedlings for sufficient time. Abou El-Souod et al. (2005) reported the control of $R$. solani, $M$. phaseolina and $P$. debaryanum producing damping-off and root rot on Phaseolus vuligaris seedling with a group of fungicides.

A successful disease-control program could involve just a single practice, but the long term reduction of disease losses generally requires the application of several control measures. The management of soil-borne plant pathogens is particularly complex because these organisms live in or near the dynamic environment of the rhizosphere, and can frequently survive a long period in soil through the formation of resistant survival structures.

A new technology for plant disease control is based on the activation of the plant's own defense system with aid of low molecular weight synthetic molecules that induce systemic acquired resistance (SAR) in plants against a wide range of microbial pathogens. SAR and induced systemic (ISR) are two forms of the induced resistance. Plant defenses are preconditioned by prior infection or treatment that results in resistance (or tolerance) against subsequent challenge by pathogen (Vallad and Goodman, 2004). The ISR sensitizes the plant to respond rapidly after treatment. These responses include activation of peroxidase, polyphenoloxidase and phenylalanine ammonia lyase and phenols (Ragab et al., 2009 and Abdel Aal et al., 2012). Salicylic acid (SA) represents an interesting new opportunity in controlling fungal and bacterial diseases with in an environmental friendly integrated system (Ellis et al., 2002; El-Khallal, 2007; Ali, et al., 2009 and Yehia, et al., 2011). Several investigators studied the effectiveness of these chemical inducers on root rot disease (Segarra et al., 2006). Salicylic acid (SA) has 
been used successfully to control some plant diseases such as root rot of cucumber (Chen-Chunquan et al., 1999), root rot/wilt of sesame (Abdou et al., 2001), root rot of wheat (El-Bana et al., 2002) and root rot of tomato (ElKhallal, 2007 and Suprakash ojha, 2012). Farah bakhsh and Shams addin (2011) observed the improvement in maize vegetative growth following SA application under saline condition and concluded that the positive reaction of this material on plant growth may be due to the chemical changes in plants throughout avoiding the uptake undesired ions $\mathrm{Na}^{+}$and $\mathrm{Cl}^{-}$and enhancing the uptakes of $\mathrm{No}_{3}^{-}, \mathrm{Mg}^{+2}, \mathrm{Fe}^{+2}, \mathrm{Mn}^{+2}$ and $\mathrm{Cu}^{+2}$.

The aim of work presented in this paper, was to assess the efficacy of salicylic acid (SA) on the induction of SAR in cantaloupe and squash plants compared to the action with three fungicides widely used for management of damping-off and root rot under field conditions. Also to identify some associated biochemical changes in treated plants.

\section{MATERIALS AND METHODS}

\section{1- Isolation, purification and identification:}

Roots of diseased Melon and squash plants were collected from field of Etay El-Baroud Agric. Res., Station, El Beheria Governorate, and washed with tap water to remove adhering soil particles. Small parts of infected roots were surface sterilized using sodium hypochloride solution (3\%) for three minutes, washed with distilled sterilized water for several times, then dried using sterilized filter paper and transferred into petri-dishes containing potato dextrose agar medium (PDA). Plates were incubated at $25^{\circ} \mathrm{C}$ for three days. All grown fungi were purified using single spore or hyphal tip technique and identified according to Dhingra and Sinclair (1985), Booth (1977), Domsch et al. (1980) and Singh (1982).

\section{2- In vitro experiment:}

A laboratory study was performed to examine the sensitivity of $R$. solani and $F$. solani to salicylic acid (SA) which obtained from Sigma chemical Co. Aqueous solution of SA was dissolved in ethanol (95\%) and added to distilled water at room temperature to prepare the stock suspensions. Sterile distilled water was also used to prepare stock preparations of three fungicides Telcolofos-methyl/thiram (rizolex-T WP 50\%), Flutolanil (moncut WP 30\%) and Carboxin-Thiram (vitavax-200 WP) at rates of 0,50,100, $200 \mathrm{ppm}$ singly or in combinations with SA. The required concentrations were obtained by adding the appropriate amount of stock solution to $100 \mathrm{ml}$ of autoclaved PDA before solidification. Discs ( $6 \mathrm{~mm}$ diameter) cut from the actively growing regions of four-day old $R$. solani and $F$. solani culture using cork borer were placed in the center of each petri dish. There were three replicates of nine dishes /treatment for each pathogen. Petri dishes were covered with Parafilm and incubated at $25^{\circ} \mathrm{C}$ for five days. The diameter of growth on petri dish was recorded in centimeter when mycelial growth of control covered the plates. The reduction percentage of growth (RG) ratio was calculated using the following formula (Amer, 1995):

$\mathrm{RG} \%=[\mathrm{RNT}-\mathrm{RT} / \mathrm{RNT}] \times 100$ Where:

RNT = Radius for non-treated media, and RT $=$ Radius for treated media 


\section{3- Field experiment:}

Salicylic acid and the three fungicides either single or in combinations were prepared in concentrations as mentioned in (Table, 1 ) by dissolving in distilled water with $1 \mathrm{~mL}$ of Arabic gum $/ 100 \mathrm{~mL}$ suspension. The seeds of cantaloupe $c v$. Mera and squash cv. Askandrany were soaked for 7 hours in any of the desired concentration, and then kept in cheesecloth bags for 12 hours before sowing. Germinated seeds were sown at 15 May in two successive growing seasons 2012 and 2013 . The field plots $\left(12 \mathrm{~m}^{2}\right)$ consisted of three terraces of $4 \mathrm{~m}$ long and $1 \mathrm{~m}^{2}$ in width, two seeds/hil were sown with $30-40 \mathrm{~cm}$ a spacing distance for hills in fields naturally infested with dampingoff and root rot fungi. Untreated seed were used as control. All agricultural practices were carried out according to the recommendation of the Ministry of Agriculture and Land Reclamation, Egypt. Located at the experimented farm of Etay El- Baroud Agric., Res., Station, Beheria Governorate.

Table (1):Salicylic acid and fungicides used for controlling the studied fungi under field condition.

\begin{tabular}{|l|c|c|c|}
\hline Commercial name & Common name & Chemical name & $\begin{array}{c}\text { Application } \\
\text { rate/Liter }\end{array}$ \\
\hline Salicylic acid & Salicylic acid & o-hydroxbenzic acid & $1.0 \mathrm{~g} / \mathrm{L}$ \\
\hline Moncut WP 30\% & Flutolanil & $\begin{array}{c}\text { N-(3-(1-methylethoxy)-2- } \\
\text { (trifuoromethyl)benzamide }\end{array}$ & $2.0 \mathrm{~g} / \mathrm{L}$ \\
\hline Rizolex T WP 50\% & $\begin{array}{c}\text { Telcolofos- } \\
\text { methyl/thiram }\end{array}$ & $\begin{array}{c}20 \% \text { Telcolofos- methyl }(0,2,6 \\
\text { dichloro-4methyl-phenyl 0,0 } \\
\text { dimethyl phosporo thioate) and 30\% } \\
\text { thiram. }\end{array}$ & $3.0 \mathrm{~g} / \mathrm{L}$ \\
\hline $\begin{array}{l}\text { Vitavax 200 WP } \\
75 \%\end{array}$ & Carboxin-Thiram & $\begin{array}{c}\text { Carboxin: (5,6-Dihydro-2 methyl-N- } \\
\text { phenyl-1.4-oxathiin-3-carboxamide) } \\
\text { Thiram (tetramethyl thiuram } \\
\text { disulfide) }\end{array}$ & $2.0 \mathrm{~g} / \mathrm{L}$ \\
\hline
\end{tabular}

Treatments used:

1- Check (Tap water)

2- Salicylic acid (SA)

3- Moncut WP 30\% (Mo)

4- Rizolex WP $50 \%(\mathrm{Rz})$

5- Vitavax 200 WP $75 \%$ (V200)

6- $\mathrm{SA}+\mathrm{Mo}$

7- $\mathrm{SA}+\mathrm{Rz}$

8- $S A+V 200$

After 45 days from sowing, plant leaves were collected from each treatment for determining peroxidase and polyphenoloxidase activities. Growth parameters as shoot length $(\mathrm{cm})$, fresh and dry weight/plant $(\mathrm{g})$ were measured.

\section{Disease assessment:}

Pre- and post- emergence damping-off disease were assessed two and four weeks after sowing, then the survival plants was counted according to the following formula (Mona et al., 2009):

Pre-emergence $(\%)=$ Total No. of ungerminated seeds $\times 100$

$$
\text { Total No. of planted seeds }
$$




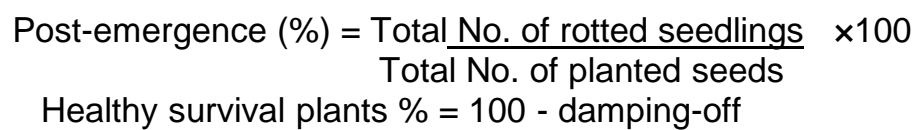

4- Enzyme determinations:

Peroxidase assay:

Peroxidase activity was spectrophotometrically determined by measuring the oxidation of tetraguciaol in the present of $\mathrm{H}_{2} \mathrm{O}_{2}$ at $470 \mathrm{~nm}$ according to the method described by Kato and Shimizu (1987). A sample of $0.25 \mathrm{gm}$ fresh weight was homogenized with phosphate buffer PH6 and centrifuged for $15 \mathrm{~min}$ at $4000 \mathrm{rpm}$. The enzyme activity was assayed by mixing $1 \mathrm{ml}$ of crude enzyme extract, $0.3 \mathrm{ml}$. of $7.2 \mathrm{mM}$ tetraguciaol and 0.1 $\mathrm{ml}$. of $11.8 \mathrm{mM} \mathrm{H}_{2} \mathrm{O}_{2}$. The enzyme activity was expressed as $\mathrm{A}_{470} / \mathrm{min} / \mathrm{gm}$ of fresh weight. Enzyme activity was expressed in units of $\mu \mathrm{M}$ of the substrate converted per min per gram fresh weight. Each value reported is the average of three replicates.

Polyphenoloxidase assay:

The activity of polyphenoloxidase was determined according to the method of Esterbaner et al., (1977). $0.25 \mathrm{gm}$ of fresh weight was homogenized in borate buffer, $\mathrm{PH} 7$. The homogenate was centrifuged at $4000 \mathrm{rpm}$ for $15 \mathrm{~min}$. one $\mathrm{ml}$ of crude enzyme extract mixed with $1.01 \mathrm{ml}$ of $0.2 \mathrm{M}$ sodium phosphate buffer $\mathrm{PH} 7$ and $1 \mathrm{ml}$ of $10^{-3} \mathrm{M}$ catechol. The reaction mixture was incubated for $1 \mathrm{~h}$. at $40^{\circ} \mathrm{C}$. After briefly vortexing, the absorbance at $490 \mathrm{~nm}$ was then determined. The activity was expressed as $\mathrm{A}_{490} / \mathrm{min} \mathrm{gm}$ of fresh weight. Each value reported is the average of three replicates.

\section{Micro elements analysis:}

Accurately weighted sample $(3 \mathrm{~g})$ in crucible was subjected to ashing in furnace for 4 hour at $550 \mathrm{C}$. After cooling in desiccators, $2.5 \mathrm{~mL}$ of $6 \mathrm{~N} \mathrm{HNO}_{3}$ was added to crucible. The solution was analyzed for $\mathrm{Fe}, \mathrm{Mn}$ and $\mathrm{Zn}$ by using Atomic Absorption Spectrophotometer (AAS-Perkin Elmer, Model analyst 800). The results were extrapolated while using a working standard of 1000 ppm for each of the species (Hussain et al., 2009 and 2010).

\section{5- Statistical analysis:}

Data obtained were subjected to the statistical analysis according to the standard methods recommended by (Gomez and Gomez, 1984) using the computer program (costate). Means were compared using L.S.D. at the level $5 \%$ of probability and Duncan 's multiple range test at $p<0.05$ level was used for means separation (Winer, 1971).

\section{RESULTS AND DISCUSSION}

\section{1- In vitro experiments:}

Data presented in Table (2) and illustrated in Figure (1) revealed that salicylic acid (SA) and fungicides, moncut (Mo), rizolex (Rz) and vitavax200 (V200) either individually or in combinations significantly reduced linear growth $(\mathrm{cm})$ of both $R$. solani and $F$. solani. The lowest linear growth of $R$. solani was achieved by $\mathrm{SA}+\mathrm{V} 200$ with the average of $3.52 \mathrm{~cm}$ followed by V200 and SA+Rz with an average of 3.90 and $4.12 \mathrm{~cm}$, respectively. In 
general, statistical analysis cleared that there are significant difference between the average linear growth values between the SA and fungicides treatments. In this regard Ghada and Abdel-Sattar (2013) who found that capritop, moncut, rizolex $T$ and shirlan at $20 \mathrm{ppm}$ reduced the linear growth of F. solani, R. solani and Monosporascus cannonballus isolated from diseased roots of cantaloupe. In this respect Saad, et al. (2014) reported complete inhibition of mycelial growth by vitavax 200 at 200 ppm and reached $95.59 \%$ at $100 \mathrm{ppm}$. Vitavax 200 inhibited the linear growth of $F$. solani by 24.15 $100 \%$, respectively. The combinations between SA and fungicides in the present study were more effective than using any of them individually. $\mathrm{SA}+\mathrm{V} 200$ and $\mathrm{SA}+\mathrm{Rz}$ at $200 \mathrm{ppm}$ were the most effective where they recorded the highest reduction percentages of $R$. solani and $F$. solani with the averages of $84.75,86.79 \%, 71.25$ and 87.13 , respectively. These results are in agreement with finding of Abdel-Monaim (2013) who mentioned that biocontrol agents combined with chemical inducers recorded the highest inhibition of growth of pathogenic fungi, especially in case of SA+ Trichoderma viride and SA+ Bacillus megaterium. The inhibitory effect produced by $S A$ in the present study almost agrees with that found by Hilal et al. (2006) who found that salicylic acid (SA) completely prevented the mycelial growth of Sclerotinia sclerotiorum using the concentration $4.0 \mathrm{~g} / \mathrm{L}$. Abdel-Monaim (2012) showed that the highest inhibitory effect on $F$. oxysorum. f. sp. lycopersici isolates was noticed when 200 ppm of $\mathrm{H}_{2} \mathrm{O}_{2}$ was added to liquid and soild media followed by SA at 200 ppm. In addition, obtained results by Abdel-Monaim et al. (2012) showed that the linear growth of $F$. oxysorum, F. solani and $R$. solani decreased by using SA at $200 \mathrm{ppm}$ for the previous pathogens, while liner growth reduced from $90 \mathrm{~mm}$ in check treatment to $54.93,48.60$ and $65.45 \mathrm{~mm}$ in case of $F$. oxysorum, $F$. solani and $R$. solani, respectively. 
Table (2): Effect of salicylic acid (SA) and fungicides individually or in combinations on linear growth $(\mathrm{cm})$ of $R$. solani and $F$. solani under laboratory conditions.

\begin{tabular}{|c|c|c|c|c|c|c|c|}
\hline Treatment & $\begin{array}{c}\text { Conc. } \\
\text { ppm }\end{array}$ & R. solani & ${ }^{\star}$ Mean & $\begin{array}{c}\text { Inhibition } \\
(\%)\end{array}$ & F. solani & ${ }^{\star}$ Mean & $\begin{array}{c}\text { Inhibition } \\
(\%)\end{array}$ \\
\hline SA & $\begin{array}{c}0 \\
50 \\
100 \\
200 \\
\end{array}$ & $\begin{array}{l}7.58 \\
5.71 \\
5.17 \\
4.00 \\
\end{array}$ & $5.62 \mathrm{a}$ & $\begin{array}{c}- \\
24.67 \\
31.79 \\
47.23 \\
\end{array}$ & $\begin{array}{l}8.00 \\
5.53 \\
4.51 \\
4.03 \\
\end{array}$ & $5.52 \mathrm{a}$ & $\begin{array}{c}- \\
30.88 \\
43.63 \\
49.63 \\
\end{array}$ \\
\hline Mo & $\begin{array}{c}0 \\
50 \\
100 \\
200\end{array}$ & $\begin{array}{l}7.68 \\
5.17 \\
4.30 \\
3.43\end{array}$ & $5.15 b$ & $\begin{array}{c}- \\
32.68 \\
44.01 \\
55.34\end{array}$ & $\begin{array}{l}8.10 \\
4.32 \\
2.76 \\
2.37\end{array}$ & $4.39 \mathrm{~b}$ & $\begin{array}{c}- \\
46.67 \\
65.93 \\
70.74\end{array}$ \\
\hline Rz & $\begin{array}{c}0 \\
50 \\
100 \\
200 \\
\end{array}$ & $\begin{array}{l}8.12 \\
3.50 \\
3.40 \\
2.40 \\
\end{array}$ & $4.36 \mathrm{~cd}$ & $\begin{array}{c}- \\
56.89 \\
58.13 \\
70.44 \\
\end{array}$ & $\begin{array}{l}8.00 \\
3.03 \\
2.27 \\
1.50 \\
\end{array}$ & $3.70 \mathrm{c}$ & $\begin{array}{c}- \\
62.13 \\
71.63 \\
81.25 \\
\end{array}$ \\
\hline V200 & $\begin{array}{c}0 \\
50 \\
100 \\
200\end{array}$ & $\begin{array}{l}7.88 \\
3.54 \\
2.40 \\
1.77\end{array}$ & $3.90 \mathrm{e}$ & $\begin{array}{c}- \\
55.08 \\
69.54 \\
77.53\end{array}$ & $\begin{array}{l}7.87 \\
2.70 \\
1.70 \\
1.30\end{array}$ & $3.39 \mathrm{~cd}$ & $\begin{array}{c}- \\
65.69 \\
78.40 \\
83.48\end{array}$ \\
\hline $\mathrm{SA}+\mathrm{Mo}$ & $\begin{array}{c}0 \\
50 \\
100 \\
200 \\
\end{array}$ & $\begin{array}{l}7.94 \\
3.75 \\
3.50 \\
3.30 \\
\end{array}$ & $4.62 \mathrm{c}$ & $\begin{array}{c}- \\
52.77 \\
55.92 \\
58.44\end{array}$ & $\begin{array}{l}7.94 \\
4.03 \\
2.99 \\
2.03 \\
\end{array}$ & $4.25 \mathrm{~b}$ & $\begin{array}{c}- \\
49.24 \\
62.34 \\
74.43 \\
\end{array}$ \\
\hline$S A+R z$ & $\begin{array}{c}0 \\
50 \\
100 \\
200\end{array}$ & $\begin{array}{l}8.00 \\
3.33 \\
2.83 \\
2.30\end{array}$ & $4.12 \mathrm{de}$ & $\begin{array}{c}- \\
58.38 \\
64.63 \\
71.25\end{array}$ & $\begin{array}{l}8.00 \\
2.80 \\
2.23 \\
1.03\end{array}$ & $3.52 \mathrm{~cd}$ & $\begin{array}{c}- \\
65.00 \\
72.13 \\
87.13\end{array}$ \\
\hline$S A+V 200$ & $\begin{array}{c}0 \\
50 \\
100 \\
200 \\
\end{array}$ & $\begin{array}{l}7.41 \\
3.26 \\
2.27 \\
1.13 \\
\end{array}$ & $3.52 \mathrm{f}$ & $\begin{array}{c}- \\
56.01 \\
69.37 \\
84.75 \\
\end{array}$ & $\begin{array}{l}7.80 \\
2.47 \\
1.73 \\
1.03 \\
\end{array}$ & $3.26 \mathrm{~d}$ & $\begin{array}{c}- \\
68.33 \\
77.82 \\
86.79 \\
\end{array}$ \\
\hline L.S.D. 0.05 & \multicolumn{3}{|c|}{$\begin{array}{l}\text { Conc. }=0.217 \\
\text { Treat. }=0.288 \\
\mathrm{C} \times \mathrm{T}=0.575\end{array}$} & & \multicolumn{2}{|c|}{$\begin{array}{c}\text { Conc. }=0.236 \\
\text { Treat. }=0 . .312 \\
\mathrm{C} \times \mathrm{T}=0.625\end{array}$} & \\
\hline
\end{tabular}

SA:Salicylic acid, Mo: Moncut WP 30\%, Rz: Rizolex WP 50\%, V200: Vitavax $20075 \%$

* Average diameter was calculated for each tested concentration based on three replicates 


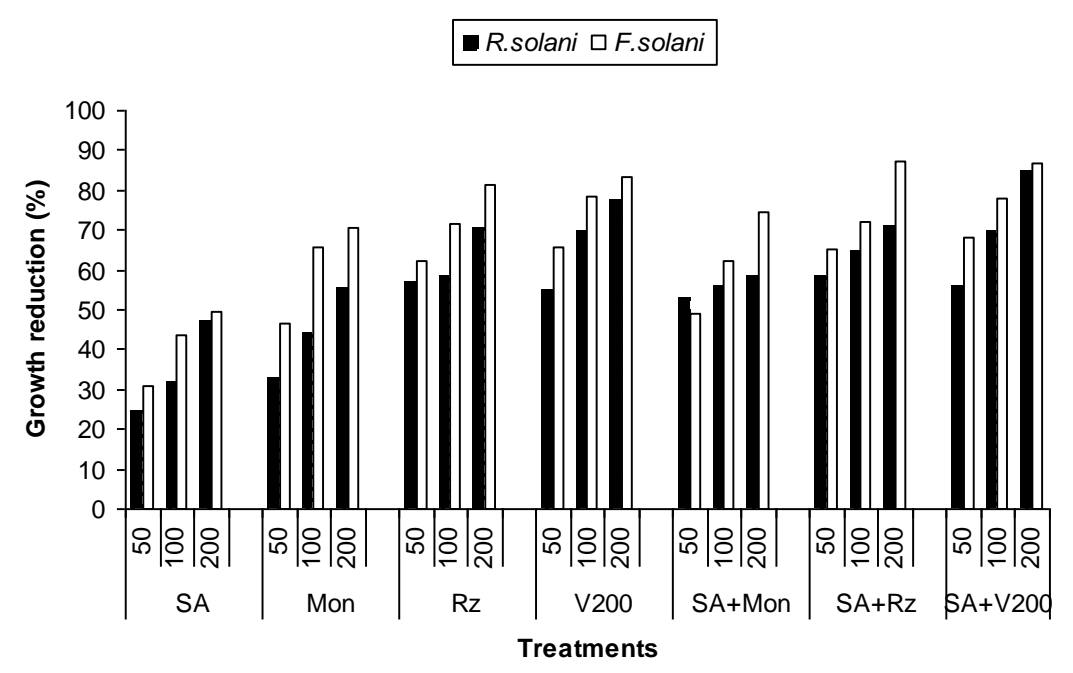

Fig. (1): Effect of salicylic acid (SA) and fungicides individually or in combinations on reduction percentages of mycelial growth of $R$. solani and $F$. solani under laboratory conditions.

\section{2- Effect of SA and fungicides on disease incidence in field trials:}

Table (3) shows that soaking squash and cantaloupe seeds in SA solution combined with fungicides being more effective than each of them alone. In the first season 2012, squash seed soaking in SA+Rz and SA+V200 was more effective to reduced total damping-off with the averages of 19.17 and $20.83 \%$, respectively, and increased survival plants with the averages of 80.83 and 79.17 , respectively. It is well established that SA naturally occurs in plants in very low amounts. It has been identified as an important signaling element involved in establishing the local and systemic disease resistance response of plants after pathogen attack (Alvarez, 2000). Salicylic acid levels often increase and induce the expression of pathogenesis related proteins and initials the development of systemic acquired resistance and hypersensitive response (Gruner et al., 2003 and Kachroo et al., 2005). Moreover, these results are in agreement with those reported by Nandakumar et al. (2001) who reported that the combined application methods of increased the durability of ISR in rice plants. The results of the present study confirmed the systemic nature of resistance against the pathogens which is induced through exogenous application of SA. However, Soad (2010) reported that all the combination treatments as Equation pro, Mancozeb plus ascorbic acid and salicylic acid were more effective in control of the early blight disease than the fungicide alone. Amel et al. (2010) found that, disease incidence (DI\%) was highly significantly reduced up to $0 \%$ with dipping of tomato root seedlings in Trichoderma harzianum combination with $\mathrm{SA}$ and thiophanate methyl fungicide at half recommended dose compared with the control infected with $F$. oxysporum. The present study (Table, 3 ) shows that soaking cantaloupe seeds in SA+V200, SA+Rz and V200 
decreased the total damping-off with the averages of 22.23, 25.56 and $27.78 \%$, respectively that being expressed by the survived plants. In contrast single treatment with SA and Mo recorded the lowest effect on the total damping-off with the averages of 41.11 and $33.33 \%$, respectively. These results are in agreement with the finding of Harun and Craig (2007) who showed that in the artificially infestation with Thielaviopsis basicola, causing black root rot of cotton, decreased disease severity by the combination of fungicide (systhane) and Bion than using chemical alone, but these differences were not significant than the fungicide alone.

Table (3): Effect of seed soaking in SA and fungicides individually and/or in combinations on controlling damping-off, root rot of squash and cantaloupe plants under field conditions during growing first season 2012.

\begin{tabular}{|c|c|c|c|c|c|c|c|c|c|}
\hline \multirow{2}{*}{\begin{tabular}{|l|}
$\begin{array}{l}\text { Tested } \\
\text { plants }\end{array}$ \\
\end{tabular}} & \multirow{2}{*}{\begin{tabular}{c|} 
Disease \\
incidence (\%)
\end{tabular}} & \multicolumn{8}{|c|}{ Treatment } \\
\hline & & \begin{tabular}{|l|} 
Check \\
\end{tabular} & SA & Mo & $\mathbf{R z}$ & V200 & SA+Mo & SA+Rz & SA+V200 \\
\hline \multirow{5}{*}{$\begin{array}{l}\text { Squash } \\
\text { Askandarany }\end{array}$} & Pre-emergence & 39.17 & 24.17 & 20.00 & 18.33 & 16.67 & 15.83 & 12.50 & 12.50 \\
\hline & \begin{tabular}{|l|} 
Post-emergence \\
\end{tabular} & \begin{tabular}{|l|}
16.67 \\
\end{tabular} & 13.33 & 9.17 & 10.00 & 9.17 & 11.67 & 6.67 & 8.33 \\
\hline & Total damping-off & 55.84 & 37.50 & 29.17 & 28.33 & 25.84 & 27.50 & 19.17 & 20.83 \\
\hline & Efficiency \% & \begin{tabular}{|l|}
$----^{-}$ \\
\end{tabular} & 32.84 & 47.76 & 49.27 & 53.72 & 50.75 & 65.67 & 62.70 \\
\hline & Survival & 44.16 & 62.50 & 70.83 & 71.67 & 74.16 & 72.50 & 80.83 & 79.17 \\
\hline L.S.D 0.05 & \multicolumn{9}{|l|}{$\begin{array}{l}\text { Pre }=5.86 \\
\text { Post }=4.92 \\
\text { Survival }=5.52\end{array}$} \\
\hline \multirow{5}{*}{$\begin{array}{l}\text { Cantaloupe } \\
\text { Mera }\end{array}$} & Pre-emergence & 36.00 & 27.78 & 22.22 & 21.11 & 18.89 & 21.11 & 16.67 & 15.56 \\
\hline & Post-emergence & 16.67 & 13.33 & 11.11 & 10.00 & 8.89 & 10.00 & 8.89 & 6.67 \\
\hline & Total damping-off & 52.67 & 41.11 & 33.33 & 31.11 & 27.78 & 31.11 & 25.56 & 22.23 \\
\hline & Efficiency \% & \begin{tabular}{|l|}
------- \\
\end{tabular} & 21.95 & 36.72 & 40.93 & 47.26 & 40.93 & 51.47 & 57.79 \\
\hline & Survival & 47.33 & 58.89 & 66.67 & 68.89 & 72.22 & 68.89 & 74.44 & 77.77 \\
\hline L.S.D 0.05 & \multicolumn{9}{|l|}{$\begin{array}{l}\text { Pre }=4.08 \\
\text { Post }=3.53 \\
\text { Survival }=5\end{array}$} \\
\hline
\end{tabular}

Table (4) showed similar trend in the second season 2013. Seed soaking in $\mathrm{SA}+\mathrm{V} 200$ followed by $\mathrm{SA}+\mathrm{Rz}$ were the best for reducing total damping-off with the averages of 15.83 and 19.16, respectively. Also treatment V200 decreased the total damping-off with the average of $22.50 \%$ for squash plants and revealed on the survival plants of the two previous treatments recorded $84.17,80.83$ and $77.50 \%$, respectively. These results are in accordance with Abou El-Souod et al. (2005) who recorded that vitavax was the most effective against $R$. solani, M. phaseolina and $P$. debaryanum which causes dampingoff and root rot on Phaseolus vuligaris seedling. These results confirm with those mentioned by Agostini et al. (2003), who reported that induced resistance products were effective for disease control but they may be more useful in an integrated program with standard fungicides. In several management strategies, the addition of resistance inducing chemicals in combination with biocontrol agents has significantly enhanced disease control. The result her in is in harmony with the opinion of (Shyamala and Sivakumaar, 2012 and Abdel-Monaim, 2013). Moreover, cantaloupe seed 
soaking in $\mathrm{SA}+\mathrm{V} 200, \mathrm{~V} 200$ and $\mathrm{SA}+\mathrm{Rz}$ recorded the best effect in reducing total damping-off with the average of $17.77,21.11$ and $21.12 \%$, respectively and these results reflected on increased efficiency, which was recorded with the average of $62.89,55.92$ and $55.90 \%$ respectively.

Table (4): Effect of seed soaking in SA and fungicides individually and/or in combinations on controlling damping-off, root rot of squash and cantaloupe plants under field conditions during growing second season 2013.

\begin{tabular}{|c|c|c|c|c|c|c|c|c|c|}
\hline \multirow{2}{*}{$\begin{array}{l}\text { Tested } \\
\text { plants }\end{array}$} & \multirow{2}{*}{$\begin{array}{c}\text { Disease } \\
\text { incidence (\%) }\end{array}$} & \multicolumn{8}{|c|}{ Treatment } \\
\hline & & Check & SA & Mo & $\mathbf{R z}$ & V200 & SA+Mo & SA+Rz & SA+V200 \\
\hline \multirow{5}{*}{$\begin{array}{c}\text { Squash } \\
\text { Askandarany }\end{array}$} & Pre-emergence & 37.50 & 22.50 & 18.33 & 15.00 & 14.17 & 16.67 & 10.83 & 10.00 \\
\hline & Post-emergence & 15.83 & 11.67 & 10.83 & 7.50 & 8.33 & 10.83 & 8.33 & 5.83 \\
\hline & Total damping-off & 53.33 & 34.17 & 29.16 & 22.50 & 22.50 & 27.50 & 19.16 & 15.83 \\
\hline & Efficiency \% & ------ & 35.93 & 45.32 & 57.81 & 57.81 & 48.43 & 64.07 & 70.32 \\
\hline & Survival & 46.67 & 65.83 & 70.84 & 77.50 & 77.50 & 72.50 & 80.84 & 84.17 \\
\hline \multicolumn{10}{|c|}{\begin{tabular}{|ll} 
L.S.D 0.05 & Pre $=3.85$ \\
& Post $=4.42$ \\
& Survival $=7.75$
\end{tabular}} \\
\hline \multirow{5}{*}{$\begin{array}{c}\text { Cantaloupe } \\
\text { Mera }\end{array}$} & Pre-emergence & 32.33 & 26.67 & 21.11 & 17.78 & 14.44 & 20.00 & 15.56 & 13.33 \\
\hline & Post-emergence & 15.56 & 12.22 & 11.11 & 7.78 & 6.67 & 8.89 & 5.56 & 4.44 \\
\hline & Total damping-off & 47.89 & 38.89 & 32.22 & 25.56 & 21.11 & 28.89 & 21.12 & 17.77 \\
\hline & Efficiency \% & -----י & 18.79 & 32.72 & 46.63 & 55.92 & 39.67 & 55.90 & 62.89 \\
\hline & Survival & 52.11 & 61.11 & 67.78 & 74.44 & 78.89 & 71.11 & 78.88 & 82.23 \\
\hline .S.D 0.05 & $\begin{array}{l}\text { Pre }=2.82 \\
\text { Post }=3.12 \\
\text { Survival }=3.78\end{array}$ & & & & & & & & \\
\hline
\end{tabular}

SA: Salicylic acid, Mo: Moncut WP 30\%, Rz: Rizolex WP 50\%, V200: Vitavax $20075 \%$

\section{2. a- Effect of SA and fungicides on growth parameters in field trials:}

Table (5) shows the results of squash and cantaloupe seed soaking in SA solution combined with any one of the fungicides significantly improved squash and cantaloupe growth more than used each of the individually except in case of SA+Mo treatment. Also seed soaking in SA individually activated plant growth in both seasons 2012 and 2013. The highest fresh weights in the 2012 season were obtained from the combinations of $\mathrm{SA}+\mathrm{V} 200$ and $\mathrm{SA}+\mathrm{Rz}$ with the averages of 32.45 and $28.13 \mathrm{gm} /$ squash plant and 25.64 and $23.73 \mathrm{gm} /$ cantaloupe plant, respectively. In case of dry weight the above two treatments had an averages of 4.09 and $3.07 \mathrm{gm} /$ squash plant and 3.48 and $3.03 \mathrm{gm} /$ cantaloupe plant, respectively. In the second season, the results were approximately the same as in the first season especially with $\mathrm{SA}+\mathrm{V} 200, \mathrm{SA}+\mathrm{Rz}$ and $\mathrm{SA}$. These increases may be attributed to $S A$ which plays an important role on various physiological processes in plants such as ion uptake, cell elongation, cell division, enzymatic activation and protein synthesis. In this respect, Sakabutdinova et al. (2003) reported that treatment of wheat plants with SA $0.05 \mathrm{M}$ increased the level of cell division within the apical meristem of seedling roots which caused an increase in plant growth. In this regard, the exogenous application of SA had effected positively the growth and flowering of marigold plants (Calendula officinalis L.). Plants treated with $1 \mathrm{mM}$ of SA showed the highest 
leaf number, leaf dry mass and leaf area with the averages of 79.16, 69.24 and 59.95\%, respectively (Pacheco et al., 2013).

Table (5): Effect of seed soaking in SA and fungicides individually and/or combinations on fresh, dry weight and shoot length of squash and cantaloupe plants under field conditions during two successive seasons (2012and 2013).

\begin{tabular}{|c|c|c|c|c|c|c|c|c|c|c|c|c|}
\hline \multirow[b]{3}{*}{ Treatment } & \multicolumn{6}{|c|}{ Squash (Askandarany) } & \multicolumn{6}{|c|}{ Cantaloupe (Mera) } \\
\hline & \multicolumn{3}{|c|}{2012} & \multicolumn{3}{|c|}{2013} & \multicolumn{3}{|c|}{2012} & \multicolumn{3}{|c|}{2013} \\
\hline & 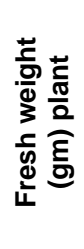 & 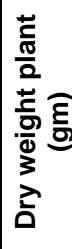 & 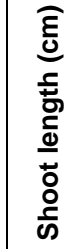 & 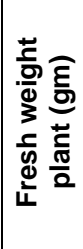 & 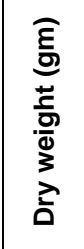 & 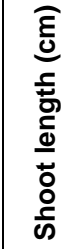 & 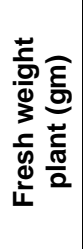 & 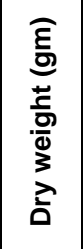 & 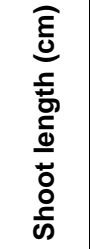 & 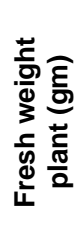 & 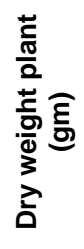 & 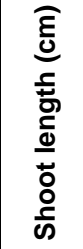 \\
\hline SA & 27.00 & 3.01 & 33.25 & 30.82 & 3.65 & 39.00 & 19.51 & 3.04 & 30.75 & 23.75 & 3.31 & 32.75 \\
\hline Mo & 18.81 & 2.02 & 22.00 & 19.63 & 2.29 & 24.00 & 14.19 & 2.07 & 24.00 & 16.19 & 2.60 & 28.63 \\
\hline $\mathrm{Rz}$ & 21.06 & 2.59 & 26.00 & 27.22 & 2.92 & 30.63 & 17.83 & 2.72 & 28.25 & 20.68 & 3.21 & 32.33 \\
\hline V200 & 22.53 & 2.81 & 31.00 & 30.83 & 3.54 & 37.00 & 16.36 & 2.77 & 29.00 & 18.61 & 3.08 & 31.38 \\
\hline $\mathrm{SA}+\mathrm{Mo}$ & 20.64 & 2.15 & 26.25 & 22.21 & 2.34 & 27.00 & 15.91 & 2.63 & 25.25 & 22.98 & 2.79 & 27.00 \\
\hline$S A+R z$ & 28.13 & 3.07 & 36.63 & 32.49 & 4.15 & 40.00 & 23.73 & 3.03 & 31.00 & 25.85 & 3.47 & 34.33 \\
\hline$S A+V 200$ & 32.45 & 4.09 & 40.25 & 35.34 & 4.91 & 42.63 & 25.64 & 3.48 & 35.75 & 28.17 & 3.64 & 37.00 \\
\hline Check & 13.04 & 1.59 & 20.75 & 15.31 & 1.72 & 21.75 & 10.34 & 1.40 & 20.00 & 11.31 & 1.47 & 24.00 \\
\hline L.S.D 0.05 & 4.14 & 0.524 & 3.00 & 3.18 & 0.349 & 2.820 & 1.43 & 0.347 & 1.698 & 1.42 & 0.448 & 1.85 \\
\hline
\end{tabular}

SA: Salicylic acid, Mo: Moncut WP 30\%, Rz: Rizolex WP 50\%, V200: Vitavax $20075 \%$

\section{2.b-Changes in polyphenoloxidase (PPO) and peroxidase (PO) activities:}

Data in Table (6) show that all treatments either single or in combinations with SA have increased the activity of both PPO and PO over the check. Peroxidase activity was markedly increased after treatments with of $\mathrm{SA}+\mathrm{V} 200, \mathrm{SA}+\mathrm{RZ}$ and V200 followed by SA for squash plants with an average of $0.895,0.795,0.720$ and 0.699 activity/min, respectively. Meanwhile, combinations of SA with V200 and either Rz or V200 individually recorded the highest increase in PPO enzyme activity with averages of 0.579 , 0.545 and 0.507 activity/min respectively. In case of cantaloupe SA+V200 and $S A+R z$ had the highest values for peroxidase activity followed by SA with averages of $0.998,0.861$ and 0.670 , respectively. The same trend being obvious in case of polyphenoloxidase where $\mathrm{SA}+\mathrm{V} 200$ and $\mathrm{SA}+\mathrm{Rz}$ had the highest values but $\mathrm{Rz}$ followed them with averages of $0.575,0.560$ and 0.533 , respectively. The least activity however, was recorded for Mo treatment on both PPO and PO for squash and cantaloupe plants. The activity of both PPO and PO are naturally present in plant tissues. Polyphenoloxidase converts polyphenolic compounds to the oxidized form quinines which are thought to be inhibitory to pathogens invasion. Also it was found that the highest peroxidase activity was usually more active in resistant cultivars (Pradeep and Jambhale, 2002).Moreover, Amel et al. (2010) reported that combination of salicylic acid with Trichoderma as seedling 
tomato root dipping (SA+T2) and Fungicide (thiophanate methyl) with its half recommended dose $(S A+0.5 F)$ increased $P P O$ and POD activities. Similar results also gave evidence to the role of $S A$ on tomato plants treated with different concentrations of SA had accesses in the activities of both peroxidase and polyphenoloxidase. The combined application of SA and $T$. harzianum enhanced activities of both enzymes in Fusarium infected tomato plants (Suprakash Ojha, 2012).

Table (6): Effect of seed soaking in SA and fungicides individually and/or in combinations on activities of peroxidase and polyphenoloxidase as optical density/minute/gm fresh weight in leaf extracts of squash and cantaloupe plants.

\begin{tabular}{|c|c|c|c|c|c|c|c|c|c|}
\hline \multirow{2}{*}{$\begin{array}{l}\text { Tested } \\
\text { plants }\end{array}$} & \multirow{2}{*}{$\begin{array}{l}\text { Enzyme } \\
\text { activity }\end{array}$} & \multicolumn{8}{|c|}{ Treatment } \\
\hline & & Check & SA & Mo & $\mathbf{R z}$ & V200 & SA+Mo & SA+Rz & SA+V200 \\
\hline \multirow[b]{2}{*}{$\begin{array}{l}\text { Squash } \\
\text { Askandarany }\end{array}$} & $\begin{array}{c}\text { Peroxidase }^{*} \\
\text { (PO) }\end{array}$ & 0.345 & 0.699 & 0.558 & 0.645 & 0.720 & 0.635 & 0.795 & 0.895 \\
\hline & $\begin{array}{c}\text { Polyphenol- } \\
\text { oxidase }^{\star *} \\
\text { (PPO) }\end{array}$ & 0.134 & 0.461 & 0.444 & 0.545 & 0.507 & 0.474 & 0.495 & 0.579 \\
\hline L.S.D 0.05 & \multicolumn{9}{|l|}{$\begin{array}{l}\text { Po }=0.107 \\
\text { PPo }=0.091\end{array}$} \\
\hline \multirow[b]{2}{*}{$\begin{array}{l}\text { Cantaloupe } \\
\text { Mera }\end{array}$} & $\begin{array}{l}\text { Peroxidase }^{*} \\
\text { (PO) }\end{array}$ & 0.383 & 0.670 & 0.518 & 0.617 & 0.619 & 0.653 & 0.861 & 0.998 \\
\hline & \begin{tabular}{|c|}
$\begin{array}{c}\text { Polyphenol- } \\
\text { oxidase }{ }^{\star *} \\
\text { (PPO) }\end{array}$ \\
\end{tabular} & 0.159 & 0.515 & 0.419 & 0.533 & 0.529 & 0.499 & 0.560 & 0.575 \\
\hline L.S.D 0.05 & \multicolumn{9}{|l|}{$\begin{aligned} \mathrm{Po} & =0.125 \\
\mathrm{PPo} & =0.093\end{aligned}$} \\
\hline
\end{tabular}

SA: Salicylic acid, Mo: Moncut WP 30\%, Rz: Rizolex WP 50\%, V200: Vitavax 200 75\%

${ }^{\star}$ Peroxidase activity expressed as change in absorbance at $470 \mathrm{~nm} / \mathrm{g}$ fresh weight/15min.

**Poly phenol oxidase activity expressed as change in absorbance at $575 \mathrm{~nm} / \mathrm{g}$ fresh weight/15min.

From the afore-mentioned data an opposite correlation between the PPO or PO enzyme activities and total disease incidence was recognized. Table (7) shows the values of correlation coefficient ( $r$ ) confirmed the results obtained previously, where a negative correlation were noticed between the disease incidence and PPO and PO enzyme activities. This correlation reached 59.5 and $82.9 \%$ for squash PPO and PO enzyme activities and 71.3 and $74.7 \%$ for cantaloupe. These results are in harmony with the results mentioned by Pena and Ankue (1992) and Nawar and Kuti (2003) who indicated a positive relation between resistance and peroxidase activity. Peroxidase also produces free radicals and hydrogen peroxidase which are toxic to many microorganisms. Also, Morsy (2005) reported that the susceptibility of the four lentil cvs. was positively correlated with the activity of peroxidase, polyphenoloxidase and b 1-3 glucanase, where cv. Sinai 1 (more resistant to $R$. solani and $F$. oxysporum tested fungi) recorded the highest enzymes activity whereas cv. Giza 9 (highly susceptible) recorded the lowest enzymes activity. It could be generally concluded that salicylic acid mixing 
with fungicides may be increased the fungicidal potentials against dampingoff and root rot diseases along with enhancement of enzymes related resistance in squash and cantaloupe.

Table (7): Correlation coefficient between disease incidence \% and each of peroxidase and polyphenol oxidase activities.

\begin{tabular}{|l|c|c|}
\hline \multirow{2}{*}{ Variable } & \multicolumn{2}{|c|}{ Linear correlation coefficient $(r)$} \\
\cline { 2 - 3 } & Squash & Cantaloupe \\
\hline Peroxidase activity $\left(\mathrm{AA}_{470}\right.$ Min/mg port.) & -0.595 & -0.713 \\
\hline Polyphenol oxidase activity (Unit x100 Port.) & -0.829 & -0.747 \\
\hline
\end{tabular}

2. c- Micronutrients in squash and cantaloupe plants:

From Table (8), the application of salicylic acid either single or in combinations with fungicides caused a significant increase in the content of $\mathrm{Zn}, \mathrm{Fe}$ and $\mathrm{Mn}$, in squash and cantaloupe plants. The maximum values of $\mathrm{Fe}$ and $\mathrm{Mn}$ micronutrients contents were obtained with $\mathrm{SA}+\mathrm{V} 200, \mathrm{SA}+\mathrm{Rz}, \mathrm{SA}$ and $\mathrm{SA}+\mathrm{Mo}$ treatments in both squash and cantaloupe, contrary to $\mathrm{SA}$ treatment that decreased $\mathrm{Zn}$ content. These results are consistent with those reported by Fahad and Bano (2012) who observed that microelements of $\mathrm{Co}^{+3}, \mathrm{Mn}^{+2}, \mathrm{Cu}^{+3}$ and $\mathrm{Fe}^{+2}$ increased in roots of $\mathrm{SA}$ treated maize plants under salinity stress which may help in stimulating metabolic reaction of plants. These micronutrients also assist in enhancing enzymatic activity, Munns, (2005). On the other hand, $\mathrm{Na}{ }^{+}, \mathrm{Ni}^{+3}, \mathrm{~Pb}^{+4}$, and $\mathrm{Zn}^{+2}$ content decreased in roots of SA treated in maize plants. Fatma (2006) found that SA applied at $10^{-4}$ and $10^{-5} \mathrm{M}$ show increased the content of $\mathrm{N}, \mathrm{P}, \mathrm{K}, \mathrm{Fe}, \mathrm{Mn}$ and $\mathrm{Cu}$ in Ocimum basilicum and Majorana hortensis, except $\mathrm{P}$ (in case of basil) and $\mathrm{Zn}, \mathrm{Na}$ and $\mathrm{Cu}$ content (in case of marjoam). Similarly foliar application of SA caused an increase in mean Mn uptake of chick pea shoot by about $7 \%$. Meanwhile the effect of SA on mean $\mathrm{Zn}$ uptake in chickpea shoot was negligible. (Ghasemi-Fasaei, 2013). In retrospect, the preplanting soaking in SA may be recommended for extensive studies with other crops. 
Table (8): Effect of seed soaking in SA and fungicides individually and/or in combinations on micro-elements content (ppm) of squash and cantaloupe plants.

\begin{tabular}{|l|c|c|c|c|c|c|}
\hline \multicolumn{1}{|c|}{ Plant } & \multicolumn{3}{c|}{ Squash } & \multicolumn{3}{c|}{ Cantaloupe } \\
\hline Micro-elements & Zn & Fe & Mn & Zn & Fe & Mn \\
Treatment & & & & & & \\
\hline SA & 48.40 & 0.326 & 40.82 & 46.53 & 0.390 & 39.80 \\
\hline Mo & 62.90 & 0.285 & 32.39 & 63.10 & 0.267 & 32.88 \\
\hline Rz & 63.90 & 0.295 & 36.64 & 61.00 & 0.326 & 36.41 \\
\hline V200 & 60.40 & 0.298 & 36.74 & 63.93 & 0.317 & 34.40 \\
\hline SA+Mo & 50.90 & 0.320 & 37.87 & 55.10 & 0.335 & 38.58 \\
\hline SA+Rz & 50.65 & 0.402 & 37.60 & 53.10 & 0.339 & 45.87 \\
\hline SA+V200 & 50.63 & 0.438 & 54.16 & 52.10 & 0.462 & 54.94 \\
\hline Check & 54.47 & 0.310 & 35.99 & 56.20 & 0.317 & 35.85 \\
\hline L.S.D 0.05 & 0.500 & 0.049 & 0.521 & 0.739 & 0.065 & 0.568 \\
\hline
\end{tabular}

SA: Salicylic acid, Mo: Moncut WP 30\%, Rz: Rizolex WP 50\%, V200: Vitavax $20075 \%$

\section{REFERENCES}

Abdel Aal, A.E.; Abd-El-Kader, Dawlat A.; Khedr, M.A. and Khalifa, M.M.A. (2012). Induction of resistance in sesame plants against charcoal rot disease by some chemical inducers. Zagazig J. Agric. Res., 39: 189-202.

Abdel-Kader, M.M.; El-Mougy, N.S.; Aly, M.D.E.; Lashin, S.M. and ElMohamady, R.S. (2012). Soil drench with fungicides alternatives against root rot incidence of some vegetables under greenhouse conditions. International Journal of Agriculture and Forestry 2 (2): 61-69.

Abdel-Monaim, M.F. (2012). Induced systemic resistance in tomato plants against Fusarium wilt disease. Int. Res. J. Microbiol. 3(1): 14-23.

Abdel-Monaim, M.F. (2013). Improvement of biocontrol of damping-off and root rot/wilt of faba bean by salicylic acid and hydrogen peroxide. Plant Pathology Research Institute, Agric., Res. Center, Giza 41: (1): 47-55.

Abdel-Monaim, M.F.; Abdel-Gaid, M.A.W. and Armanious, H.A.H. (2012). Effect of chemical inducers on root rot and wilt diseases, yield and quality of tomato. International Journal of Agricultural Sciences ISSN: 2167-0447 2(7): 210-220.

Abdou El-S; Abd-Alla H.M. and Galal, A.A. (2001). Survey of sesame root rot/wilt disease in Minia and their possible control by ascorbic and salicylic acid. Assuit J. of Agric. Sci., 32 (3): 135-152.

Abou El-Souod, S.M.; Amer, S.M.; Asawah, S.W.; Ismail, A.A.; Abou Zeid, A.M. and Moubark, H.M. (2005). Effect of some fungicides, heavy metals and their combinations against some pathogenic fungi for Phaseolus vulgaris. Assiut Univ. J. of Botany 34: 115-130. 
Agostini, J.P.; Bushong, P.M. and Timmer, L.W. (2003). Green house evaluation of products that induce host resistance for control of scab, melanose and Alternaria brown spot of citrus, Plant Disease. 87: 69-74.

Ali, A.A.; Ghoneem, K.M.; Metwally, M.A. and Abd El-Hai, K.M. (2009). Induce systemic resistance in lupine against root rot diseases. Pakistan Journal of Biological Sciences 12(3): 213-221.

Alvarez, M.E. (2000). Salicylic acid in the machinery of hypersensitive cell death and disease resistance. PI. Mol. Biol., 44: 429-442.

Amel A. H; Soad M. A. and Ismail, A.A. (2010). Activation of tomato plants defense response against Fusarium wilt disease using Trichoderma harzianum and Salicylic acid under greenhouse conditions. Research Journal of Agriculture and Biological Sciences, 6(3): 328-338.

Amer, M.A. (1995). Evaluation of adjuvants to enhance fungicide efficacy against plant pathogens. Ph.D. Thesis, Faculty of Agric. Appl. Sci., University of Gent, Belgium.

Booth, C. (1977). Fusarium laboratory guide to the identification of the major species. Commonwealth Mycological Institute, Kew surey, England, pp. 130-153.

Celar, F. (2000). Cucurbit diseases. Sodono Kmetijstvo., 33: 162-165.

Chen-Chunquan, S.; Belanger, R.R.; Benhamou, N.; Paulitz, T.C. and Chen, C.Q. (1999). Role of salicylic acid in systemic resistance induced by Pseudomonas spp. against Pythium aphanidermatum in cucumber roots. European J. Plant Pathol., 105: 477-486.

Dhingra, O.D.; and Sinclair, J.B. (1985). Basic plant pathology methods. $2^{\text {nd }}$ ed. CRC, Boca Raton, Florida, USA, 434 PP.

Domsch, K. H.; Gams, W. and Anderson, T.H. (1980). Compendium of soil fungi. vol. 1 Academic press, London. $859 \mathrm{pp}$.

El-Bana, A.A.; Ismaial, A.A.; Nageeb, M.N. and Galal, A.A. (2002). Effect of irrigation intervals and salicylic acid treatments on wheat root rot and yield components. Proc. Minia 1st Conf. for Agric. And Environ. Sci., Minia, Egypt, March 25-28: 229-240.

El-Khallal, S.M. (2007). Induction and modulation of resistance in tomato plants against Fusarium wilt disease by bioagent fungi (Arbuscular mycorrhiza) and/or hormonal elicitors (jasmonic acid and salicylic acid): 1- Changes in growth, some metabolic activities and endogenous hormones related to defense mechanism. Australian J. Basic and Appl. Sci., 1 (4): 691-705.

Ellis, C.; Karafullidis, L. and Turner, J.G. (2002). Constitutive action of jamonate signaling in an Arobidopsis mutant correlates with enhanced resistance to Erysiphe cichoracearumPseudomonas syrinage and Myzus persicae. Mol Plant Micro Interact., 15: 1025-1030. 
El-Mougy, N.S.; Abdel-Kader, M.M.; Abdel-Kareem, E.I.; Embaby, R. ElMohamady and Abd El-Khair, H. (2011). Survey of fungal diseases affecting some vegetable cropsand their rhizospheric soilborne microorganisms grown under protected cultivation system in Egypt. Research Journal of Agriculture and Biological Sciences, 7 (2): 203-211.

Esterbaner, H.; Schwarzl, E. and Hayn, M. (1977). In: Principles of Biochemistry (Publisher: Freeman. W.H.), 477:486.

Fahad, S. and Bano, A. (2012). Effect of salicylic acid on physiological and biochemical characterization of maize growth in saline area. Pak. J. Bot., 44 (4): 1433-1438.

Farah bakhsh, H. and Shams addin, S. M. (2011). Effect of foliar application of salicylic acid on vegetative growth of maize under saline conditions. Afr. J. Plant Sci. 5: 575-578.

Fatma A. G. (2006). Effect of salicylic acid on growth, metabolic activities and oil content of basil and marjoram. International Journal of Agriculture \& Biology. 4 (8): 485-492.

Ghada A.A. El-Kolaly and Abdel-Sattar, M.A. (2013). Biological and chemical control of sudden wilt disease of cantaloupe in Egypt. Journal of American Science 9 (11): 100-108.

Ghasemi-Fasaei, R. (2013). Influence of foliar application of salicylic acid and soil application of humic materials on cucumber and chickpea grown on a nutrient deficient soil. International Journal of Agriculture and Crop Sciences. 5(21) 2639-2644.

Gomez, K.A. and Gomez, A.A. (1984). Statistical procedures for agricultural research 2 nod, John Weley and Sons, Inc., New York.

Gruner, R.; Strompen, A.; Pfitzner, J.P. and Pfitzner, U.M. (2003). Salicylic acid and the hypersensitive response initiate distinct signal transduction pathways in tobacco that converge on the as-l-like element of the Pr-I a promoter European J. Biochem., 270:4876.

Harun, T. and Craig, S.R. (2007). Efficacy of seed treatment chemicals, including fungicides and host resistance inducers, in controlling the black root rot pathogen, Thielaviopsis basicola, on cotton. Summaries of Arkansas Cotton Research. AAES Research Series 562: $129-132$.

Hibar, K., M. Daami-Remadi, W. Hamada and M. El-Mahjoub, (2006). Bio-fungicides as an alternative for tomato Fusarium crown and root rot control. Tunisian Journal of plant Protection, 1: 19-29.

Hilal. A.A.; Nada, M.G.A. and Wafaa H. Zaky (2006). Induced resistance against Sclerotinia sclertiorum disease in some Umbelliferous medicinal plants as a possible and effective control mean. Egypt. J. Phytopathol., 34: 85-101.

Hussain, J.; Khan, A.L.; Rehman, N.; Ullah, Z.; Hussain, F. Khan and Shinwari, Z.K. (2009). Proximate and nutrient analysis of selected medicinal plant species of Pakistan. Pakistan J. Nut., 8(1): 620-624. 
Hussain, J.; Rehman, N.; Khan, A.L.; Hamayun, M.; Hussain, S.M. and Shinwari, Z.K. (2010). Proxmate and nutrients evaluation of selected vegetables species from Kohat Region Pakistan. Pakistan Pak. J. Bot., 42 (4): 2847-2855.

Joseph, A. (1994). Emerging technologies for the control of post-harvest diseases of fresh fruit and vegetables, p. 1-10 in Biological Control of Post-Harvest Diseases. Theory and Practice. Charles L. Wilson and Michael, E. Wisniewski (Eds.), CRCPress, $182 \mathrm{pp}$.

Kachroo, P.; Venngopal, S.C. Nvarre, D.A.; Lapchyk, I. and Kachroo, A. (2005). Role of salicylic acid and fatty acid desaturation pathway in ssi-mediated signaling. Pant, Physiol., 139: 1717-1735.

Kato, M. and Shimizu, S. (1987). Chlorophyll metabolism in higher plants. VII. Chlorophyll degradation in dependent peroxidative degradation. Can. J.Bot., 65: 729-735.

Mona M.M. Ragab; Saber, M.M.; El-Morsy, S.A. and Abeer A.R. Abd ElAziz (2009). Induction of systemic resistance against root rot of basil using some chemical inducers. Egypt. J. Phytopathol., 37: 5970.

Morsy, K.M.M. (2005). Induced resistance against damping-off, root rot and wilt diseases of lentil Egypt. J. Phytopathol., 33 (2): 53-63.

Munns, R. (2005). Genes and salt tolerance: bringing them together. New Phytol., 167 (3): 45-663.

Nandakumar, S.; Babu, V. R.; Sheela, J.; Raguchander, T. and Samiyappan, R. (2001). A new bio-formulation containing plant growth promoting rhizobacterial mixture for the management of sheath blight and enhanced grain yield in rice, Biol. Control. 46: 494-510.

Nawar, H.F. and Kuti, J.A. (2003). Wyereon and phytoalexin ynthesis and peroxidase activity as markers for resistance of broad beans to chocolate spot disease. J. Phytopathol., 151: 564-570.

Olfulolaju, D.B. (1993). Evaluation of some relatively new fungicides for smut control in Nigeria. Crop Protection, 13: 293-295.

Pacheco, A.C.; Cabral, C.S.; Fermino, E.S.S and Aleman, C. C. A. (2013). Salicylic acid-induced changes to growth, flowering and flavonoids production in marigold plants. Journal of Medicinal Plant Research 7(42): 3162-3167.

Pena, M. and Ankue, J. A. (1992). Peroxidase -generated hydrogen peroxidase as a source of antifungal activity in vitro and on tobacco leaf disks. Phytopathology. 82: 696-690.

Pradeep, T. and Jambhale, N.D. (2002). Relationship between phenolics, polyphenol oxidase and peroxidase, and resistance to powdery mildew in Zizyplus Phytopathol. 55 (5): 195-196.

Rukhsana Afzal, S.M.; Mughal, M.; Kishwar, S.; Rehmatullah, Q.; Muhammad, A. and Laghari, M.K. (2010). Mycoflora associated with seed of different sunflower cultivars and its management. Pakistan J. Bot. 42(1): 435-445. 
Saad, A.S.A; Kadous, E.A.; Tayeb, E.H.; Massoud, M.A.; Soad M.A. and Abou El-ELA, A.S.A. (2014). The inhibitory effect of some antioxidants and fungicides on the growth of Alternaria solani and Fusarium solani in vitro. Middle East Journal of Agriculture Research, 3(2): 123-134.

Sakabutdinova, A.R.; Fatkhutdinova, D.R.; Bezrukova, M.V. and Shakirova, F.M. (2003). Salicylic acid prevents the damaging action of stress factors on wheat plants. Bulgarian Journal of Plant Physiology, Special Issue, 314-319.

Segarra, G.; Jauregui, O.; Casanova, E.; and Trillas, I. (2006). Simultaneous quantitative LC-ESI-MS/MS analyses of salicylic acid and jasmonic acid in curde extracts of Cucumis sativus under biotic stress. Phtochemistry. 67 (4): 395-401.

Shyamala, L. and Sivakumaar, P.K. (2012). Integrated control of blast disease of rice using the antagonistic Rhizobacteria Pseudomonas fluorescens and the resistance inducing chemical salicylic acid. International Journal of Research in Pure and Applied Mlicrobiology. 2 (4): 59-63.

Singh, R. S. (1982). Plant Pathogens "The fungi" Oxford and IBH publishing CO. New Delhi. Bombay, Calcutta, 443 pp.

Soad M. Ahmed (2010). Effects of salicylic acid, ascorbic acid and two fungicides in control of early blight disease and some physiological components of two varieties of potatoes. J. Agric. Res .Kafer El-Shiekh Univ., 36: 220-237.

Suprakash ojha, N.C.C. (2012). Induction of resistance in tomato plants against Fusarium oxysporum f.sp. lycopersici mediated through salicylic acid and Trichoderma harzianum. Journal of Plant Protection Research 52: 220-225.

Vallad, G.E. and Goodman, R.M. (2004). Systemic acquired resistance and induced systemic resistance in conventional agriculture. Crop Sci., 44: 1920-1934.

Wada, A.C. (2003). Control of sugarcane smut disease in Nigeria with fungicides. Crop Protection, 22: 45-49.

Winer, B. J. (1971). Statistical principles in experimental design. 2nded. New York: McGraw Hill, USA.

Yehia A.G. Mahmoud.; Soad M. Abu El Soud; Saeid, A.; Abd-Elwahb, I.; Magid, A. and Mohsen, K. Ebrahim (2011). Recent approaches for controlling brown spot disease of faba bean in Egypt. Egypt. Acad. J. biolog. Sci., 3: 41-53. 


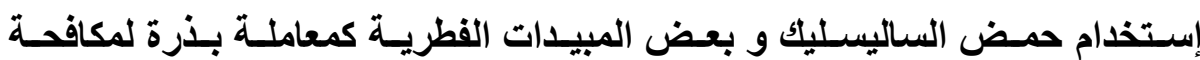

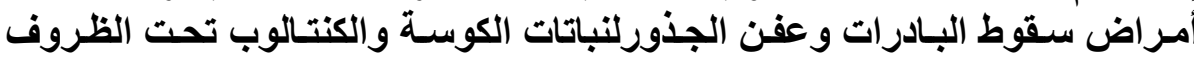
الحقلية

جهاد محمد محمد 1 وسعيدة محمد عامر 2

1- قسم بحوث أمراض الخضرة محثر - معهد بحوث أمراض النباتات ـ مركز البحوث الزراعية ـ

الجيزة

2 - قسم النبات ـ كلية العلوم - جامعة طنطا

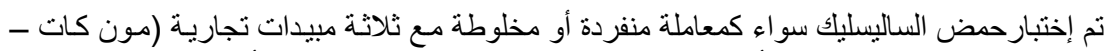

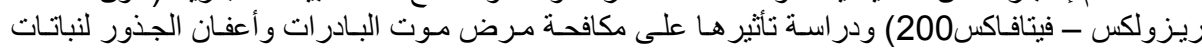

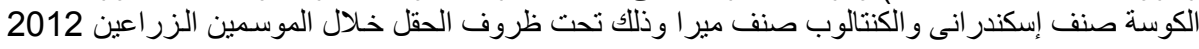
.2013,

معمليا وجد أن إستخدام حمض الساليسليك سو اء كمعاملة منفردة أو مخلوطة مع المبيدات (مون كات

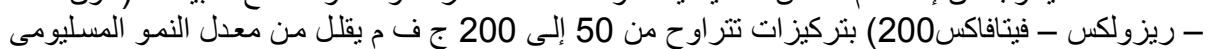

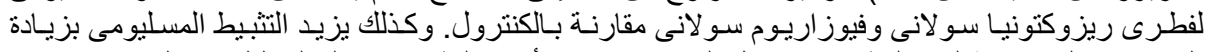

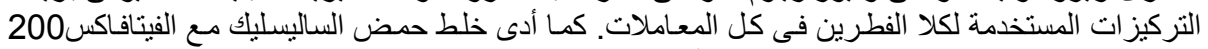

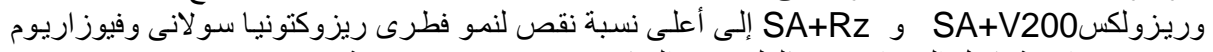

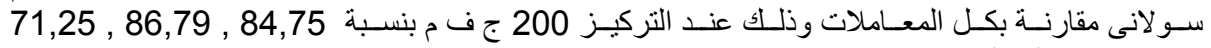

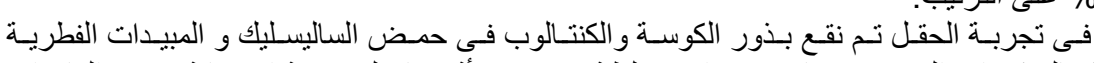

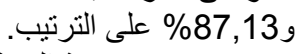

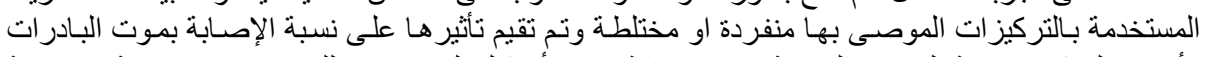

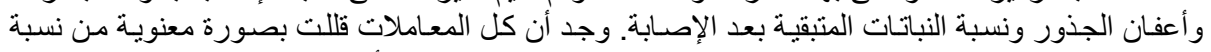

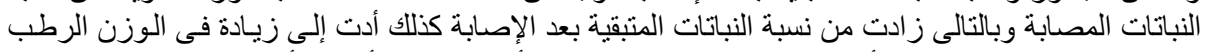
و الجاف وطول النباتات. وجد أن نقع البذور في

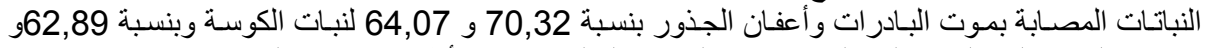

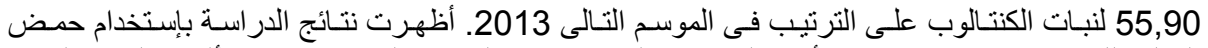

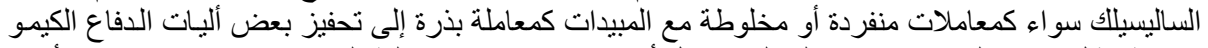

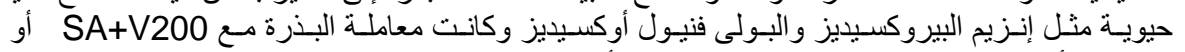

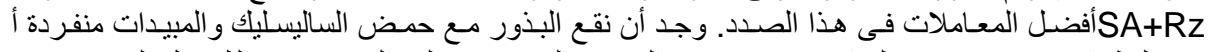
ومخاليطها يزيد من محتوى النبات من عنصرى الحديد والمنجنيز النديز وعلى النقيض من ذلك يقل المحتوى من

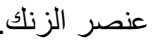

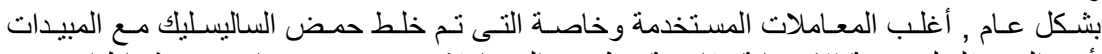

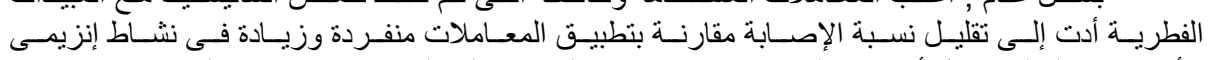

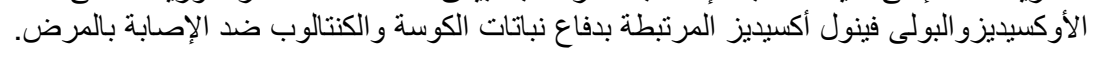




\title{
Journal of
}

\section{Plant Protection and Pathology}

\author{
Volume 5 No. (12), December, 2014
}

Established in 1976

Official Publication of Faculty of Agriculture, Mansoura University

Telefax: 0502221688 E-mail: agriournal mansuniv@hotmail.com 


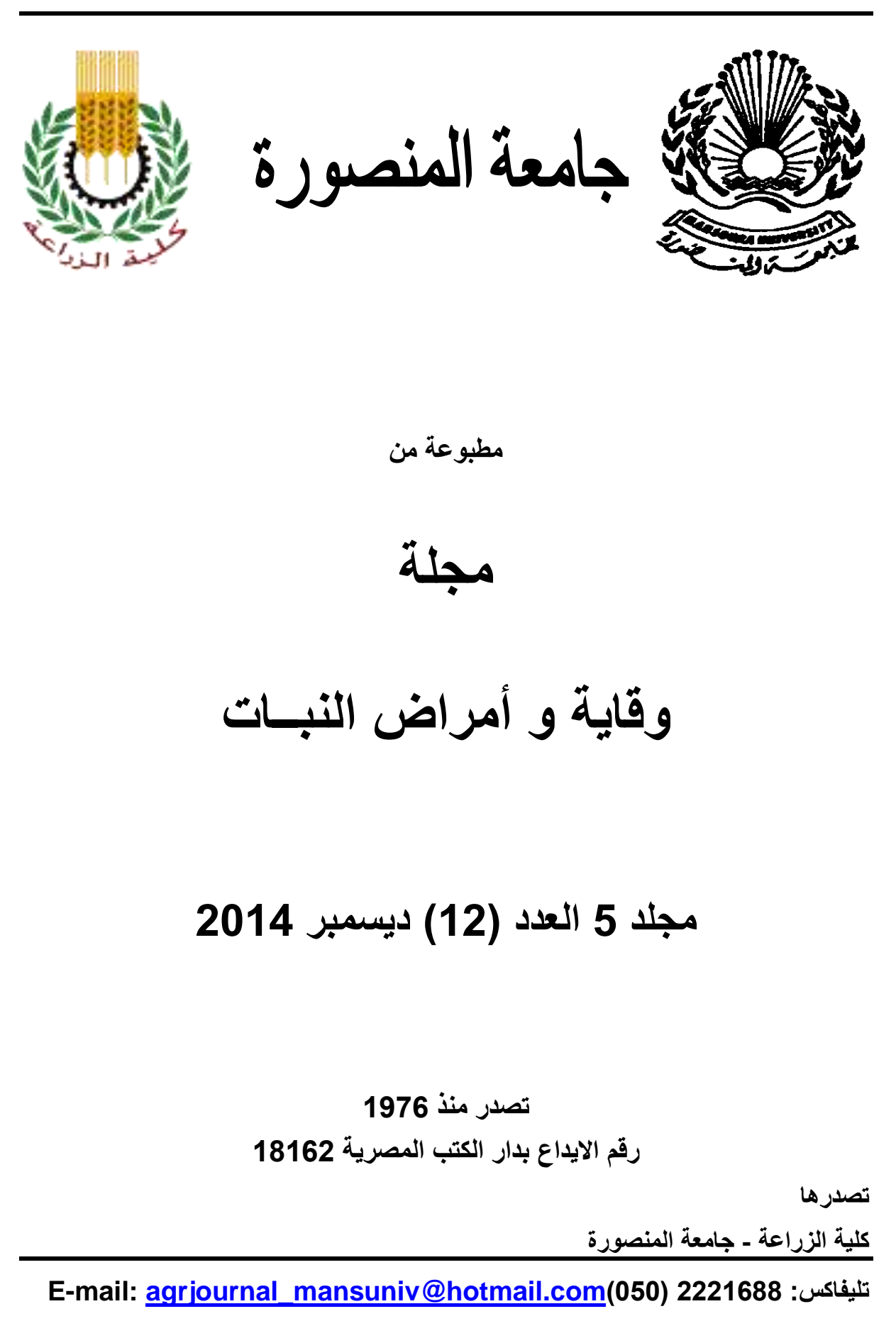

